\title{
7
}

\section{Neurodiversity.Com: A Decade of Advocacy}

\author{
Kathleen Seidel
}

\section{Introduction}

I was unschooled in autism before 1999. When Oliver Sacks's article, "An Anthropologist on Mars," appeared in The New Yorker in 1993 [1], my husband, Dave, and I had thought of our youngest child-a precocious, eccentric, artistic, excitable puzzle-lover with a penchant for solitude. "Sounds familiar!" we said to each other, but saw no reason for special concern.

I read nothing more about autism until 1999, after our first meeting with his fourth-grade teacher. ${ }^{1}$ Her classroom observations led us back to the Sacks article, which resonated anew. A psychologist encouraged us to obtain an evaluation, and after several months of testing, in mid-2000 our child was diagnosed with Asperger syndrome.

\footnotetext{
${ }^{1}$ Since mid-2006, I have consistently used masculine pronouns to refer to the person identified in many of my earlier advocacy letters as my youngest daughter.
}

K. Seidel ( $\square)$

Peterborough, NH, USA 
I set about learning everything I could about autism in order to best understand his needs and articulate those needs to his teachers. I read works by Lorna Wing [2], Uta Frith [3], Tony Attwood [4], and Simon BaronCohen [5]. I attended AANE (Asperger/Autism Network) seminars. I participated in discussions on the St. John's Autism List [6]. I trawled the internet for information and created a database to store my bookmarks and notes. I am a librarian by training, and had already developed several websites; an autism portal seemed like a potentially useful and rewarding creative project.

That took a few years to happen. After losing my job in the Dot-Com Bust of 2000, I started a used bookselling business, and underwent a profound shift in my understanding of autism.

\section{Engaging Neurodiversity}

I first encountered "neurodiversity" in an article in The Atlantic describing online spaces created by autistic adults [7]. I loved the compassionate, inclusive flavor of the word, and its broad call for respect for people like my child. I tucked it into my memory, whence it emerged one evening in January 2001, as Dave and I were brainstorming ideas for domain names. As it turned out, "neurodiversity" was available, so we registered it on the spot.

Although bookselling temporarily derailed my autism website plans, I continued to read and squirrel away URLs, increasingly gravitating to work by autistic authors. I delved into essays by Jim Sinclair [8], Frank Klein [9], Larry Arnold [10], and Joelle (then Joel) Smith [11]. I discovered the writings of Michelle Dawson, who opposed efforts in Canada to mandate one form of behavioral training as "medically necessary" for autistic children [12]. Laura Tisoncik's and Mel (then Amanda) Baggs's "Institute for the Study of the Neurologically Typical" [13] (see Tisoncik, Chapter 5) made a strong impression, and both eventually became friends. Janet NormanBain's "Oops ... Wrong Planet! Syndrome” website led to hours of exploration [14]. I gave Gunilla Gerland's Finding Out about Asperger Syndrome [15] to my child to help him understand his diagnosis. Every reading sparked new shocks of recognition. 
I began to notice autistic traits in every interaction I had with my father, and my mother-a music and special education teacher-increasingly shared that recognition. A chemical engineer born in 1933, Dad contracted polio at the age of ten, and used crutches, braces, and a wheelchair thereafter. In our household, "disability" and mobility accommodations were ordinary, as was a certain interpersonal je ne sais quoi. Dad was an analytical thinker with minimal tolerance for his own frustration or others' emotionality; he was practical, brusque, and disinclined to social niceties. (One especially memorable phone call began in mid-sentence, as if I were mid-conversation with him a continent away.) I gradually recognized that I, too, lay somewhere along the banks of the "broader autistic phenotype": intense focus; bluntness; anxiety and occasional sensory overload; fondness for collecting, organizing, and diving deeply into subjects that interest me. Why had nearly a decade passed before Dave and I figured out that our youngest child was on the spectrum? Perhaps because he was not so different from his grandfather, or from me.

\section{Neurodiversity.Com}

The appearance of "neurodiversity" in the New York Times [16] signaled that the time had come to transform my database into a website. In May 2004, after a week of nonstop HTML writing, Neurodiversity.com was born. Over 100 different pages included "Positive Perspectives on Autism," "Girls \& Women on the Spectrum," "The Question of Cure," and "Neurotypical Issues"; the site also featured a game, "Unmasking the Face" [17], based on Paul Ekman's book on nonverbal communication [18]. Later, I added a collection of papers on the history of autism research, including early works by Kanner, Asperger, and Lovaas [19].

From my original mission statement:

My goal is to increase goodwill and compassion in the world, and to help reduce suffering. I seek to help reduce the suffering of autistic children and adults, who often face extraordinary challenges in many domains of life, challenges made more difficult by others' unrealistic expectations and demands, negative judgments, harassment and marginalization. I seek to 
help reduce the suffering of family and community members who are bewildered and distressed by actions of and interactions with autistic people, and who are concerned for their own and others' safety and well-being. I seek to help increase the capability of educators and service providers to provide effective, respectful support for those on the autistic spectrum. My means of achieving that goal is to share some of the information that has helped us to move from a place of grief and stress to a place of recognition, understanding, and positive regard. [20]

\section{Engaging Advocacy}

Shortly after Neurodiversity.com launched, I noticed a visit from the Yahoo group AutAdvo; soon I was avidly participating in discussions with autistic men and women whose writings I had previously encountered. I enjoyed exchanges with Camille Clark, co-creator of the Autistic Adults Picture Project [21], who blogged from 2005 to 2007 as "Autism Diva" [22]; Jane Meyerding, author of "Thoughts on Finding Myself Differently Brained" [23]; Phil Schwarz, father of an autistic son and vice-president of AANE [24]; Kassianne Sibley (now Kassiane Asasumasu); Patricia Clark (d. 2005 [25]); Alyric (d. 2009 [26]); and many other members.

Through AutAdvo, I befriended Gayle Kirkpatrick, whose autistic son had been banned from their town's only playground, and traveled to Maine in August 2004 to attend hearings in the family's suit against the school district. Shortly before trial, I summarized many themes that would inform my subsequent advocacy work in "The Autistic Distinction":

... Those who value compassion must work to change the content and tenor of public discussion about cognitive difference. ... We must consider the negative impact on autistic citizens of the popular practice of referring to autism as an "epidemic," a "tragedy," a "plague," a "devastating scourge," a "catastrophe," or a "demon;" of the use of military metaphors such as "killing," "attacking" or "defeating" autism, and description of autistic children as "prisoners of war;" of comparison of autism with degenerative diseases such as cancer and diabetes; of the use of verbs such as "fester" to describe the autistic pattern of human development. 
... Many parents experience the unveiling of autism as a grievous revelation. However, I am convinced that the negative impact on families and on autistic persons is increased and perpetuated by crisis-oriented descriptions of autism that focus on abnormality and deficit, that automatically characterize early education as a heroic "intervention" if the children being educated are autistic, that raise the specter of institutionalization simply because that is the way society has tended to address cognitive difference in the past, and that describe autism as something that must be destroyed.

Assertions that autism can and must be "cured" create unrealistic expectations, promote the exploitation of parents made desperate by dire predictions, and perpetuate a climate of negative judgment towards children and adults who are not or do not strive to become "indistinguishable from their peers," those who look and behave like the autistic people that they are.

... I seek a reconceptualization of cognitive difference, to the end that those who bear now-stigmatizing labels of "deviance," "disorder" and "syndrome," may live and manifest their individuality, distinctive interests, gifts and capacities with integrity, in a manner that comes naturally to them, free of pressure to become people they are not, free of the automatic assignation of inferior status; and that they may enjoy the respect of their fellow citizens, rather than disdain and exclusion.

Retrospective consideration of the lives of exceptional human beings offers credible evidence that the autistic distinction has persisted throughout history, and has been a valuable element of human culture. Genetic research indicates that at least twenty different genes can signal a predisposition to autistic development; autism is pervasively embedded in the deep structure of humanity. Psychological research indicates that autistic characteristics constitute an identifiable pattern of traits that are present in varying degrees throughout our entire species.

Autism is as much a part of humanity as is the capacity to dream [27].

Through AutAdvo, I also befriended University of Wisconsin-Madison psychology professor and fellow autism mom Morton Ann Gernsbacher. When news broke that University of Kentucky chemist Boyd Haley had dubbed autism "mad child disease," we created a "Petition to Defend the 
Dignity of Autistic Citizens" that garnered hundreds of signatures after it was published on Neurodiversity.com [28]. I soon learned that Haley was a hero to many convinced that autism was vaccine-induced, and a proposed expert witness in legal proceedings consolidating thousands of claims filed by parents of autistic children. The experience strengthened my concern about the proliferation of anti-vaccinationist sentiment, litigiousness, and chronic outrage among parents of autistic children; the use of sensationalistic language to describe autism and autistic people; and the hostility toward autistic adults expressed by many proponents of an "autism epidemic."

I wrote to the Congressional Autism Caucus [29], and many more letters to editors, and documented all of the correspondence on the site. These were noticed; Neurodiversity.com was mentioned in the December 2004 New York Times piece, "How About Not Curing Us, Some Autistics Are Pleading" [30]. Later, I had encouraging exchanges with the head of the National Institute of Mental Health, who had stated that autism "robs a family of [a child's] personhood" [31], and the head of the University of California, Davis MIND Institute, whose fundraisers had broadcast insupportable claims of an "autism epidemic" [32].

After Rolling Stone published "Deadly Immunity," alleging a cover-up of evidence linking autism with vaccines, I wrote to its author, Robert F. Kennedy Jr., noting that not all parents regarded their children's autism as a consequence of wrongdoing [33]. As the publicity campaign escalated for David Kirby's book Evidence of Harm (EoH) [34], I wrote to question Kirby about the purpose of the discussion list created in connection with it, documenting many instances in which autistic children were disparaged and dissenting parents vilified [35]. I also corresponded with Lenny Schafer-proprietor of the EoH list and publisher of the Schafer Autism Report, where autistic advocates were denounced as "imposters who trivialize the catastrophic nature of real autism" [36, 37]. I did not expect that my letters to Kennedy, Kirby, and Schafer would provoke attitudinal change in their recipients, but persevered and published in the hope that visitors to Neurodiversity.com might reconsider their assumptions about autism, recognize the toxic nature of the crusade to equate autism with contamination, and increase their respect for autistic citizens of all ages. 


\section{Neurodiversity Weblog}

In the summer of 2005, I established Neurodiversity Weblog to streamline publication and facilitate discussion of letters and articles on the site. During the blog's first year [38-42], I published writing by Darold Treffert, Rita Jordan, Michelle Dawson, Phil Schwarz, and James Laidler. I deconstructed a Chronicle of Higher Education article condoning discrimination against autistic candidates for academic employment [43, 44]. I protested the Autism Society of America's pathos-inducing "Getting the Word Out about Autism" campaign [45], the use of vaccine-causation evangelists as consultants by Autism Speaks [46], and their doom-laden film Autism Every Day [47]. The blog attracted both sympathetic and critical readers, and featured many lively and occasionally contentious exchanges.

A February 2006 article in the Concord Monitor [48] spurred me to investigate a new regimen involving administration of hormonal suppressants such as Lupron to autistic children [49]. I learned that applications to patent the "Lupron protocol" remained undisclosed in the presentations of its developers, Mark and David Geier [50]; that the latter's academic affiliation was misrepresented in a peer-reviewed study [51]; that they headed the IRB overseeing their own research [52]; that they were diagnosing autistic children with precocious puberty who did not meet formal criteria [53]; and that the "protocol" called for excessive blood draws and expensive tests [54]. After publishing a series of articles on the subject [55], I sent the editorial board of Autoimmunity Reviews a lengthy critique of a report they had published of the Geiers's research [56]. This led to the paper's retraction, an incident later discussed in the British Medical Journal [57] and Slate [58].

During this period, I wrote to the Interagency Autism Coordinating Committee, calling out their lack of autistic members and their references to autism as a disease, and contrasting the scant attention they paid to quality of life issues with their frequent appeals for brain tissue, which gave the impression that autistic adults were more highly valued when dead than alive [47]. I also exchanged correspondence with the United Methodist Church protesting their support of Sykes v. Bayer, litigation initiated by a Methodist minister against corporations she held at fault for causing her son's autism [59]. 
In the fall of 2007, a paralegal studies course inspired me to write a series of articles on cases alleging environmental causation of autism. Vaccine Court Chronicles attracted heat [60]. On March 24, 2008, I published a post discussing economic incentives that biased vaccine-injury attorneys' pronouncements on disability causation, and tallied fees paid by the court to Geier associate Clifford Shoemaker [61]. Barely four hours later, Shoemaker issued a subpoena for me to be deposed in Sykes v. Bayer, demanding my financial records, tax returns, information about my religious beliefs, and all correspondence about any subject discussed on Neurodiversity.com [62].

After I blogged my motion to invalidate the subpoena, all hell broke loose. Slashdot covered the case three times, nearly crashing the server with each flood of hits [63-65]. Opinionistas across the blogosphere offered their support. Attorney Paul Levy of Public Citizen submitted a brief recommending that Shoemaker be sanctioned [66]. Harvard's Digital Media Law Project featured the case on their site [67]. I was profiled by the Concord Monitor [68], and in Andrew Solomon's New York article, "The Autism Rights Movement" [69], Dr. Paul Offit devoted a chapter to my work in Autism's False Prophets, and included me in its dedication [70]. After my motion was granted [71], Sykes $v$. Bayer was dismissed with prejudice [72], and the court ultimately sanctioned Mr. Shoemaker [73].

Over the next few years, I continued to report on ongoing autismvaccine litigation, post announcements of research participation opportunities, and investigate dodgy autism treatments and consumer scams. Subjects included OSR, an industrial chelator developed by Boyd Haley and promoted for consumption by autistic children [74], and electromagnetic radiation shielding devices touted as autism treatments by debt-ridden multilevel marketers and new-age entrepreneurs [75]. A misleading telephone solicitation provoked me to dig into the public filings of the Autism Spectrum Disorder Foundation, which claimed to help autistic people, but showed little evidence of useful activity [76]. My local paper published an op-ed in which I advised readers to be skeptical of unfounded claims about autism [77].

In 2010, my investigations of the "Lupron protocol" and OSR inspired (and were cited in) the Chicago Tribune's award-winning series on unproven autism treatments $[78,79]$. Shortly thereafter, the FDA ordered 
OSR taken off the market [80]. ${ }^{2}$ In the spring of 2011, following a Maryland citizen's complaint incorporating my articles on the "Lupron protocol," the state's Board of Physicians suspended Mark Geier's license to practice medicine and charged David Geier with practicing medicine unlawfully [82]. By 2013, Dr. Geier's license had been revoked in all twelve states that had granted it [83]. As the first person to raise the alarm about the Geier's pharmaceutical experimentation on autistic children, and about Haley's efforts to bypass federal drug approval regulations, I take pride in these outcomes.

\section{Engaging Community}

Neurodiversity.com was, for the most part, a one-woman operation; the occasional conference enabled me to connect with others who shared my interests and perspective. I was grateful to AANE for offering support to children like my son and parents like me. I learned much from AutCom's workshops on assistive communication and from accounts of its members. At Autreat 2008, I met Rosalind Picard of the MIT Media Lab [84], which I later visited with Mel Baggs and Estée Klar, founder of The Autism Acceptance Project [85]. I attended AutCom 2007 and Autreat 2009 as Mel's support person, traveling with them and assisting at their presentations.

As the amount of information and misinformation about autism proliferated online, updating Neurodiversity.com's static link pages grew increasingly laborious, and ended in 2008. The flow of blog posts lessened thanks to newfound employment; my son's labor-intensive adolescence and gender reassignment; my parents' passing; and advocacy burnout exacerbated by often-hostile attention attracted by my writing, and by the escalation of conflict between autism advocates.

In late 2005, Kevin Leitch, proprietor of the blog Left Brain/Right Brain [86] had established Autism Hub, a feed aggregator "guided by the principles of ethics, empowerment, advocacy, autism acceptance, positivity, and realism" [86]. The Hub eventually included a few dozen sites and served

\footnotetext{
${ }^{2}$ Since the FDA's 2010 order, OSR appears to have made a comeback [81].
} 
as a useful portal to positive autism advocacy. In 2007, Kev needed to cut back on his obligations, so Dave assumed responsibility for Hub maintenance. A mailing list for status updates soon morphed into a discussion forum. Over the next few years much constructive conversation ensued; increasingly, so did "horizontally hostile" exchanges. Some list members questioned the legitimacy of others' diagnoses. Several protested the continued inclusion of a blogger publishing misogynistic posts; their protest provoked misogynistic responses. Some members asked to refrain from verbal abuse griped about supposed intolerance of their "autistic communication style." Resentment was expressed that a neurotypical parent was maintaining the Hub and moderating the list. Ari Ne'eman repeatedly challenged Michelle Dawson regarding Autism Speaks's funding of Laurent Mottron's research on autistic cognition, in which she was involved [87]. I was dismayed by the emergence of this last conflict, given my respect for Dawson's work, although I agreed that Autism Speaks should retool its goals and rhetoric.

I felt that needless discord, demagoguery, and polarization could only exacerbate tensions and undermine advocacy efforts, but I had too much on my plate to jump into new debates. Dave and I were both increasingly burdened by these conflicts, as well as by a member's depressive crisis. Stressors beyond the list included efforts to discredit Mel Baggs, whose video "In My Language" [88] had attracted overwhelming media attention. In May 2010, after one too many bouts of agita, Dave took the site offline, leaving it to others to proceed without his involvement. Many were unhappy about the abrupt shutdown, but sometimes one's own sanity must come first, and we do not regret our decision.

I continued to blog as I have described above, and attended one more conference. I published my last post in March 2012 [89]; one year later, a botched server migration vaporized Neurodiversity Weblog. Fortunately, the posts can still be accessed via the Internet Archive (http://www.archive. org). Although most of Neurodiversity.com's external links are defunct, I continue to host the site as a document of autism advocacy, the debate over autism and vaccines, and the evolving idea of "neurodiversity." 
Although I own the web domain, I am reluctant to define "neurodiversity," preferring to express in writing the values I associate with it. The thoughtless deployment of stigmatizing characterizations of autism; the misleading marketing of unproven "autism treatments" to parents of autistic children; the litigation and culture of blame into which so many families were drawn-all presented morally and intellectually compelling matters for consideration, inspired by my conviction that cognitively variant persons of all ages should be afforded respect, appropriate assistance, and freedom from abuse, exploitation, and undue pathologization of their traits and challenges.

\section{Conclusion}

My path to advocacy began with the need to understand my child, and to marshal understanding within the school and community. I found the greatest insight for this work in writings of and interactions with autistic adults and their allies, both in person and online. With Neurodiversity.com and Neurodiversity Weblog, I sought first to share useful information, then to communicate my evolving concerns and encourage consideration of the concerns of autistic people themselves. I did not seek to join a movement, but ended up participating in one. As I put it in a 2006 letter to the New York Times Book Review:

The neurodiversity movement does not consist of faddish cultists trolling for converts, but of disabled individuals, their family members, and [other] allies constructively responding to prejudice, stigma and pejorative labeling. People don't all think the same way, and appreciation of this reality is not limited to those who possess a diagnosis. I am one parent who wants her "neurodiverse" family members to flourish — happily, healthily, welleducated and respected in a society that embraces the value of cognitive variety. [90] 


\section{References}

1. Sacks, O. (1993, December 27). An anthropologist on Mars. The New Yorker, 69(44), 106-125. Retrieved from https://www.newyorker.com/magazine/ 1993/12/27/anthropologist-mars.

2. Wing, L. (1998). Autistic children: A guide for parents. New York, NY: Kensington Publishing Corp.

3. Frith, U. (2003). Autism: Explaining the enigma. Malden, MA: Blackwell Publishing.

4. Attwood, T. (1997). Asperger syndrome: A guide for parents and professionals. London, UK: Jessica Kingsley Publishers.

5. Baron-Cohen, S., \& Cosmides, L. (1997). Mindblindness: An essay on autism and theory of mind. Cambridge, MA: MIT Press.

6. St. John's University. (1999-2006). Autism and developmental disabilities list (Archived website). Retrieved from https:/web.archive.org/web/ 20060113082637/http://maelstrom.stjohns.edu/archives/autism.html.

7. Blume, H. (1998, September). Neurodiversity: On the neurological underpinnings of geekdom. The Atlantic. Retrieved from https://www.theatlantic. com/magazine/archive/1998/09/neurodiversity/305909.

8. Sinclair, J. (1993). Don't mourn for us. Our Voice, 1(3). Retrieved from http://www.autreat.com/dont_mourn.html.

9. Klein, F. (2003, March 13). Autistic advocacy (Archived website). Retrieved from https://web.archive.org/web/20040319200741/http://home.att.net: $80 /$ ascaris 1 .

10. Arnold, L. (1999-2001). Kingdom of Laurentius Rex (Archived website). Retrieved from https:/web.archive.org/web/20040612094600/http://www. geocities.com/CapitolHill/7138/index.htm.

11. Smith, J. (2001-2006). This way of life. Retrieved from http://www.oocities. org/growingjoel.

12. Dawson, M. (2004, January 18). The misbehaviour of behaviourists: Ethical challenges to the autism-ABA industry. No autistics allowed. Retrieved from http://www.sentex.net/ $\sim$ nexus23/naa_aba.html.

13. Tisoncik, L., \& Baggs, M. (1999-2004). Institute for the Study of the Neurologically Typical (Archived website). Retrieved from https://web.archive.org/ web/20040611073537/http://www.autistics.org/isnt.

14. Norman-Bain, J. (1995-2005). Ooops....wrong planet! syndrome (Archived website). Retrieved from https://web.archive.org/web/20040506210446/ http://www.isn.net:80/-jypsy. 
15. Gerland, G. (2000). Finding out about Asperger syndrome, high-functioning autism, and PDD. London, UK: Jessica Kingsley Publishers.

16. Harmon, A. (2004, May 9). Neurodiversity forever: The disability movement turns to brains. The New York Times. Retrieved from https:/www.nytimes.com/2004/05/09/weekinreview/neurodiversityforever-the-disability-movement-turns-to-brains.html.

17. Seidel, K. (2004). Unmasking the face (Computer game). Neurodiversity.com. Retrieved from http://neurodiversity.com/nvc/index.html.

18. Ekman, P., \& Friesen, W. V. (1975). Unmasking the face: A guide to recognizing emotions from facial expressions. London, UK: Prentice-Hall.

19. Seidel, K. (Ed.) (2004-2005). Library of the history of autism research, behaviorism \& psychiatry (Article index). Neurodiversity.com. Retrieved from http:// neurodiversity.com/library_index.html.

20. Seidel, K. (2004b). About us (Webpage). Neurodiversity.com. Retrieved from http://neurodiversity.com/aboutus.html.

21. Norman-Bain, J., \& Clark, C. (2004). Autistic adults picture project (Archived website). Retrieved from https://web.archive.org/web/20040607004517/ http://www.isn.net/-jypsy/AuSpin/a2p2.htm.

22. Clark, C. (2005-2007). Autism Diva (Archived weblog). Retrieved from https://web.archive.org/web/20080515193436/http://www.autismdiva. blogspot.com.

23. Meyerding, J. (1998). Thoughts on finding myself differently brained (Archived webpage). M. Jane Meyerding Home Page. Retrieved from https:// web.archive.org/web/20050404121729/http://mjane.zolaweb.com:80/diff. html.

24. Schwarz, P. (2000). Personal accounts of being a university student with HFA/AS (Webpage). Retrieved from http://www.users.dircon.co.uk/ -cns/ phil.html.

25. Seidel, K. (2005, July 17). Farewell, friend: Patricia E. Clark, 1944-2005 (Archived weblog post). Neurodiversity Weblog. Retrieved from https://web.archive.org/web/20130419015004/http://neurodiversity. com/weblog/article/6.

26. Alyric. (2005-2009). A touch of alyricism (Archived weblog). Retrieved from https://web.archive.org/web/20130424135836/http://alyric.blogspot.com.

27. Seidel, K. (2004, August 20). The autistic distinction. Neurodiversity.com. Retrieved from http://neurodiversity.com/autistic_distinction.html.

28. Seidel, K. (2004, October 9). Petition to defend the dignity of autistic citizens (Webpage). Neurodiversity.com. Retrieved from http://neurodiversity.com/ mothers_for_dignity.html. 
29. Seidel, K. (2004, September 22). Autism and human rights (Webpage). Neurodiversity.com. Retrieved from http://neurodiversity.com/congressional_ autism_caucus_letter.html.

30. Harmon, A. (2004, December 20). How about not "curing" us, some autistics are pleading. The New York Times. Retrieved from https://www. nytimes.com/2004/12/20/health/how-about-not-curing-us-some-autisticsare-pleading.html.

31. Seidel, K. (2005, April 4). Autism and personhood (Webpage). Neurodiversity.com. Retrieved from http://neurodiversity.com/autism_and_ personhood.html.

32. Seidel, K. (2005, March 28). The "autism epidemic" and real epidemics (Webpage). Neurodiversity.com. Retrieved from http://neurodiversity.com/ mind_epidemic.html.

33. Kennedy, R., Jr. (2005, July 14). Deadly immunity. Rolling Stone. Retrieved from https://www.rollingstone.com/politics/politics-news/deadlyimmunity-180037.

34. Kirby, D. (2005). Evidence of harm: Mercury in vaccines and the autism epidemic. New York, NY: St. Martin's Press.

35. Seidel, K. (2005, May 29). Evidence of venom (Webpage). Neurodiversity.com. Retrieved from http://neurodiversity.com/evidence_of_venom. html.

36. Schafer, L., et al. (2005, January 11). Schafer Autism Report (Archived electronic newsletter). Retrieved from https://web.archive.org/web/ 20050507231402/http://lists.envirolink.org:80/pipermail/sareport/Weekof-Mon-20050110/000350.html.

37. Seidel, K. (2005, January 15). Lenny Schafer's inquisition: A response (Webpage). Neurodiversity.com. Retrieved from http://neurodiversity.com/ inquisition.html.

38. Dawson, M. (2005, August 1). A few questions from Michelle Dawson (Archived weblog post). Neurodiversity Weblog. Retrieved from https://web.archive.org/web/20130419015000/http://neurodiversity. com/weblog/article/25.

39. Jordan, R. (2005, August 21). Is autism a pathology? (Archived weblog post). Neurodiversity Weblog. Retrieved from https://web.archive.org/web/ 20130419015013/http://neurodiversity.com/weblog/article/45.

40. Laidler, J. (2005, July 27). Chelation and autism (Archived weblog post). Neurodiversity Weblog. Retrieved from https://web.archive.org/web/ 20130419004919/http://neurodiversity.com/weblog/article/14. 
41. Schwarz, P. (2005, August 4). Autistic people speaking about autism (Archived weblog post). Neurodiversity Weblog. Retrieved from https:// web.archive.org/web/20130419015203/http://neurodiversity.com/weblog/ article/26.

42. Treffert, D. (2005, August 10). Autism: Indeed new in name only (Archived weblog post). Neurodiversity Weblog. https://web.archive.org/web/ 20130419013009/http://neurodiversity.com/weblog/article/31.

43. Brottman, M. (2005, September 16). Nutty professors. The Chronicle of Higher Education. Retrieved from https://www.chronicle.com/article/NuttyProfessors/2488.

44. Seidel, K. (2005, October 1). Autopsy of a violent diagnosis (Archived weblog post). Neurodiversity Weblog. Retrieved from https://web.archive.org/web/ 20130131101931/http://neurodiversity.com/weblog/archives/54/.

45. Seidel, K. (2005, September 19). Getting the truth out about autism (Archived weblog post). Neurodiversity Weblog. Retrieved from https:// web.archive.org/web/20130419013006/http://neurodiversity.com/weblog/ article/51.

46. Seidel, K. (2007, January 18). On "Unstrange Minds" and the "autism epidemic" (Archived weblog post). Neurodiversity Weblog. Retrieved from https://web.archive.org/web/20130419004721/http://neurodiversity. $\mathrm{com} /$ weblog/article/123.

47. Seidel, K. (2007, January 15). Response to the Interagency Autism Coordinating Committee (Archived weblog post). Neurodiversity Weblog. Retrieved from https://web.archive.org/web/20130419005320/http://neurodiversity. $\mathrm{com} /$ weblog/article/122.

48. Conaboy, C. (2006, February 12). Did mercury cause Drew's autism? (Archived newspaper article). Concord Monitor. Retrieved from https:// web.archive.org/web/20060305223725/http://www.concordmonitor.com/ apps/pbcs.dll/article?AID=/20060212/REPOSITORY/602120310/1022/ LIVING02.

49. Seidel, K. (2006, February 19). Autism and Lupron: Playing with fire (Archived weblog post). Neurodiversity Weblog. Retrieved from https:// web.archive.org/web/20130401040535/http://neurodiversity.com/weblog/ article/83.

50. Seidel, K. (2006, April 5). Patent medicine (Archived weblog post). Neurodiversity Weblog. Retrieved from https://web.archive.org/web/ 20130401051843/http://neurodiversity.com/weblog/article/94. 
51. Seidel, K. (2006, June 9). An inaccurate byline (Archived weblog post). Neurodiversity Weblog. Retrieved from https://web.archive.org/web/ 20130401051843/http://neurodiversity.com/weblog/article/97.

52. Seidel, K. (2006, June 20). An elusive institute (Archived weblog post). Neurodiversity Weblog. Retrieved from https://web.archive.org/web/ 20130401051843/http://neurodiversity.com/weblog/article/98.

53. Seidel, K. (2006, June 26). A dubious diagnosis (Archived weblog post). Neurodiversity Weblog. Retrieved from https://web.archive.org/web/ 20130401051843/http://neurodiversity.com/weblog/article/99.

54. Seidel, K. (2006, August 25). Blood and data (Archived weblog post). Neurodiversity Weblog. Retrieved from https://web.archive.org/web/ 20130401051843/http://neurodiversity.com/weblog/article/110.

55. Seidel, K. (2006, August 25). Significant misrepresentations: Mark Geier, David Geier and the evolution of the Lupron protocol (Archived series index). Neurodiversity Weblog. Retrieved from https://web.archive.org/web/ 20130401040535/http://neurodiversity.com/weblog/article/109.

56. Seidel, K. (2006, November 17). Letter to Autoimmunity Reviews (Archived weblog post). Neurodiversity Weblog. Retrieved from https://web.archive.org/ web/20130419002523/http://neurodiversity.com/weblog/article/116.

57. Deer, B. (2007). What makes an expert? British Medical Journal, 334 (7595), 666-667.

58. Allen, A. (2008, January 30). Can vaccines cause autism? Slate. Retrieved from https://slate.com/news-and-politics/2008/01/eli-stone-scares-parentsand-angers-doctors.html.

59. Seidel, K. (2007, April 12). A plaintiff in the pulpit (Archived weblog post). Neurodiversity Weblog. Retrieved from https://web.archive.org/web/ 20130419003329/http://neurodiversity.com/weblog/article/126.

60. Seidel, K. (2008, June 2). Vaccine court chronicles (Archived series index). Neurodiversity Weblog. Retrieved from https://web.archive.org/web/ 20130401040535/http://neurodiversity.com/weblog/article/162.

61. Seidel, K. (2008, March 24). The commerce in causation (Archived weblog post). Neurodiversity Weblog. Retrieved from https://web.archive.org/web/ 20130401040535/http://neurodiversity.com/weblog/article/149.

62. Seidel, K. (2008, April 3). Subpoenaed (Archived weblog post). Neurodiversity Weblog. Retrieved from https://web.archive.org/web/20130401040535/ http://neurodiversity.com/weblog/article/150.

63. Slashdot. (2008, April 11). Blogger subpoenaed for criticizing trial lawyers (Newsgroup post). Retrieved from https://yro.slashdot.org/story/08/04/11/ 1812225/blogger-subpoenaed-for-criticizing-trial-lawyers. 
64. Slashdot. (2008, April 22). Blogger successfully quashes subpoena (Newsgroup post). Retrieved from https://yro.slashdot.org/story/08/04/22/ 1939219/blogger-successfully-quashes-subpoena.

65. Slashdot. (2008, June 24). Lawyer who subpoenaed blogger Seidel sanctioned (Newsgroup post). Retrieved from https://news.slashdot.org/story/08/06/ 24/1232258/lawyer-who-subpoenaed-blogger-seidel-sanctioned.

66. Seidel, K. (2008, May 27). Pure hearts and empty heads (Archived weblog post). Neurodiversity Weblog. Retrieved from https://web.archive.org/web/ 20130419005306/http://neurodiversity.com/weblog/article/160.

67. Ardia, D. (2008, April 11). Sykes v. Seidel (Archived webpage). Digital Media Law Project, Berkman Center for Internet and Society. Retrieved from https://web.archive.org/web/20140330234822/http:/ /www.dmlp.org/threats/sykes-v-seidel.

68. Sanger-Katz, M. (2008, April 27). A forceful voice in autism debate (Archived newspaper article). Concord Monitor. Retrieved from https:// web.archive.org/web/20080501163032/http://www.concordmonitor.com/ apps/pbcs.dll/article?AID=/20080427/FRONTPAGE/804270376.

69. Solomon, A. (2008, May 25). The autism rights movement. New York. Retrieved from http://nymag.com/news/features/47225.

70. Offit, P. (2008). Autism's false prophets: Bad science, risky medicine, and the search for a cure. New York, NY: Columbia University Press.

71. Seidel, K. (2008, April 21). Quashed! (Archived weblog post). Neurodiversity Weblog. Retrieved from https://web.archive.org/web/20130404143304/ http://neurodiversity.com/weblog/article/152.

72. Seidel, K. (2008, May 2). Mercury fades: Sykes v. Bayer dismissed (Archived weblog post). Neurodiversity Weblog. Retrieved from https://web.archive.org/ web/20130401040535/http://neurodiversity.com/weblog/article/155.

73. Seidel, K. (2008, June 23). Sanctioned (Archived weblog post). Neurodiversity Weblog. Retrieved from https://web.archive.org/web/20130401040535/ http://neurodiversity.com/weblog/article/164.

74. Seidel, K. (2008, August 1). A fine white powder (Archived weblog post). Neurodiversity Weblog. Retrieved from https://web.archive.org/web/ 20130401040535/http://neurodiversity.com/weblog/article/168.

75. Seidel, K. (2009, January 12). Who wants to be a millionaire? (Archived weblog post). Neurodiversity Weblog. Retrieved from https://web.archive.org/ web/20130401040535/http://neurodiversity.com/weblog/article/181.

76. Seidel, K. (2009, March 12). Dialing for autism dollars (Archived weblog post). Neurodiversity Weblog. Retrieved from https://web.archive.org/web/ 20130419002321/http://neurodiversity.com/weblog/article/187. 
77. Seidel, K. (2010, April 15). On autism: A word of caution (Archived weblog post). Neurodiversity Weblog. Retrieved from https://web.archive.org/web/ 20130419005312/http://neurodiversity.com/weblog/article/204.

78. Tsouderos, T. (2009, May 21). Miracle drug called junk science. Chicago Tribune. Retrieved from https://www.chicagotribune.com/lifestyles/health/ chi-autism-lupron-may21-story.html.

79. Tsouderos, T. (2010, January 17). OSR \#1: Industrial chemical or autism treatment? Chicago Tribune. Retrieved from https://www.chicagotribune. com/lifestyles/health/chi-autism-chemicaljan17-story.html.

80. Seidel, K. (2010, July 22). OSR: Off the market (Archived weblog post). Neurodiversity Weblog. Retrieved from https://web.archive.org/web/ 20130401040535/http://neurodiversity.com/weblog/article/209.

81. Carey, M. (2017, April 5). Remember the fake supplement OSR \#1? It's still being developed (Weblog post). Retrieved from https://leftbrainrightbrain. co.uk/2017/04/05/remember-the-fake-supplement-osr-1-its-still-beingdeveloped.

82. Mills, S., \& Callahan, P. (2011, May 4). Md. autism doctor's license suspended. The Baltimore Sun. Retrieved from https://www.baltimoresun.com/ health/bs-hs-autism-doctor-20110504-story.html.

83. Hawai'i Medical Board (2013, April 12). Board's final order. In the matter of the license to practice medicine of Mark R. Geier, M.D. MED 2011-79-L. Retrieved from http://web.dcca.hawaii.gov/OAHadmin/PDF_INDEX/ OAHPDF/MEDICAL\%20BOARD/MED-2011-79-L\%20MARK\%20R. \%20GEIER\%20M.D.PDF.

84. MIT Media Lab. (2008). Affective computing. Retrieved from https://www. media.mit.edu/groups/affective-computing/overview.

85. Klar, E. (2006). The autism acceptance project (Archived website). Retrieved from https://web.archive.org/web/20060623112134/http://www. taaproject.com:80.

86. Leitch, K. (2003-2007). Left brain/right brain (Archived website). Retrieved from https://web.archive.org/web/20071011015013/http:// leftbrainrightbrain.co.uk.

87. McIlroy, A. (2011, November 2). The autistic advantage: Montreal team taps researchers' potential. The Globe and Mail. Retrieved from https:// www.theglobeandmail.com/life/health-and-fitness/the-autistic-advantagemontreal-team-taps-researchers-potential/article 4182520.

88. Baggs, M. (silentmiaow). (2007, January 14). In my language (Video file). YouTube. Retrieved from https://www.youtube.com/watch?v= JnylM1hI2jc\&t=31s. 
89. Seidel, K. (2012, April 18). Geier suspension upheld (Archived weblog post). Neurodiversity Weblog. Retrieved from https://web.archive.org/web/ 20130401040535/http://neurodiversity.com/weblog/article/221.

90. Seidel, K. (2006, February 15). One for the Times (Archived weblog post). Neurodiversity Weblog. Retrieved from https://web.archive.org/web/ 20130401040535/http://neurodiversity.com/weblog/article/78.

91. Autism Hub (Archived website). Retrieved from https://web.archive.org/ web/20070102230042/http://www.autism-hub.co.uk.

Open Access This chapter is licensed under the terms of the Creative Commons Attribution 4.0 International License (http://creativecommons.org/licenses/by/ $4.0 /$ ), which permits use, sharing, adaptation, distribution and reproduction in any medium or format, as long as you give appropriate credit to the original author(s) and the source, provide a link to the Creative Commons license and indicate if changes were made.

The images or other third party material in this chapter are included in the chapter's Creative Commons license, unless indicated otherwise in a credit line to the material. If material is not included in the chapter's Creative Commons license and your intended use is not permitted by statutory regulation or exceeds the permitted use, you will need to obtain permission directly from the copyright holder.

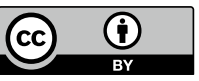

